\title{
Physical pretreatment of food waste for reducing hydrogen-consuming bacteria
}

\author{
M. H. Ting ${ }^{1}$, N. Mahmud ${ }^{1, *}$ and N.F. Ansari2 \\ ${ }^{1}$ Faculty of Industrial Sciences and Technology, Universiti Malaysia Pahang, 26300 Gambang, Pahang, Malaysia. \\ 2Department of Biotechnology, Kulliyyah of Science, International Islamic University Malaysia, 25200 Kuantan, Pahang, Malaysia.
}

\begin{abstract}
Food waste is a complex organic substrate that is also potentially hosting a variety of microbial species. In Malaysia, the large amount of food waste that is available can cause health and environmental issues due to inadequate management that has created problems such as greenhouse gas emission and release of wastewater. The utilization of food waste for value-added products is an attractive solution to reduce the accumulation of food waste, however, demands a pretreatment step to prepare the food waste for a specific production process. One interesting application of food waste is for the production of biohydrogen, which requires food waste to be free from hydrogen-consuming bacteria (HCB). This study aims to investigate the effect of physical pretreatment on food waste and suggest the best pretreatment parameters. Food waste samples were pretreated with heat at $70^{\circ} \mathrm{C}, 80^{\circ} \mathrm{C}$ and $90^{\circ} \mathrm{C}$ for 15 and 30 minutes and UV radiation for 10,15 and 30 minutes before being cultured in aerobic condition. The reduction in aerobic bacteria was measured. Heat pretreatment at $70^{\circ} \mathrm{C}$ for 15 and 30 minutes could be considered as the best pretreatment compared to the other since it recorded the highest reducing sugar concentration. Heat pretreatment at $70{ }^{\circ} \mathrm{C}$ for 15 and 30 minutes and UV radiation pretreatment for 15 minutes had a bactericidal effect and able to remove HCB. There is a high possibility that bacteria 2,7 and 8 were hydrogen-producing bacteria (HPB).
\end{abstract}

\author{
ARTICLE HISTORY \\ Received: $8^{\text {th }}$ July 2020 \\ Revised: $10^{\text {th }}$ Nov 2020 \\ Accepted: 04 ${ }^{\text {th }}$ Jan 2021
}

\section{KEYWORDS}

Pretreatment,

Biohydrogen,

Food waste

\section{INTRODUCTION}

Energy plays an important role in the development of a country. Global energy demand is expected to increase by $49 \%$ from 2007 to 2035 [1]. Global energy demand is rising rapidly due to rapid industrialization, urbanization, and population growth. Most countries rely on fossil fuels, including coal, natural gas, and oil, to meet growing energy demand. It cannot be denied that these fossil fuels have made important contributions to the development of industrialized society, but they have also adversely affected the environment and human health. The combustion of fossil fuels emit most greenhouse gases into the atmosphere and cause depletion of the ozone layer, leading to global warming. With the gradual development of industry and population, the greenhouse gas emissions phenomenon also occurred in Malaysia. In recent years, various renewable sources of energy such as wind, solar energy, hydropower, biomass, tidal energy and energy from waste are being developed to replace the fossil fuels that are easily exhausted [2].

Massive amounts of food waste are generated worldwide due to lifestyle changes, population expansion and industrial development. According to the United States (U.S.) Food and Agriculture Organization [3], almost one-third of the world's food is discarded annually. In 2013, the total amount of food waste in the U.S. rose to 37 million tons, with just 5\% (1.84 million tons) was restored, while the remaining 35 million tons were transported to landfills and incinerators [4]. In Malaysia, 15,000 tons of food is wasted daily, of which 3,000 tons are edible and do not need to be disposed of [5]. The inadequate management of waste poses a serious health and environmental hazards such as water pollution, disruption by insects and rodents, and increased flooding due to blocked drains or ditches. Moreover, it raises greenhouse gas emissions and contributes to climate change. Therefore, converting food waste into energy provides an environmentally friendly way to manage waste and generate renewable energy for sustainable development.

Hydrogen is considered a promising green energy source because of its higher energy content than other fuels [6, 7]. Hydrogen has received increasing attention as a fuel of the future because it only produces water vapour upon combustion and can be incorporated into fuel cells. Dark fermentation is an attractive biological means of producing hydrogen because it generates more hydrogen than the photofermentative process. Besides, various carbon sources can be used as substrates through the dark fermentation process, and beneficial metabolites such as butyric, lactic and acetic acids are produced. The other benefits of the dark fermentation process are no operation of the light source and no oxygen restriction. However, the low yield of hydrogen and production rate are the main problems of biological hydrogen production. The yield and production rate of hydrogen can be enhanced by optimizing the parameters such as $\mathrm{pH}$, temperature, substrate concentration, and inoculum enrichment and substrate pretreatment [8].

The utilization of food waste for biohydrogen production demands a pretreatment step to prepare the materials for the fermentation process. This includes reducing the hydrogen-consuming bacteria (HCB) and increasing the fermentable sugars [9]. Several pretreatment techniques such as physical, chemical and biological treatments have been developed [10]. Physical pretreatment is attractive due to it is a waste-free process, easy to conduct, and requires a simple unit 
operation. Food waste is a complex organic substrate that potentially hosts various microbial species, especially those associated with anaerobic digestion, including methanogens and other HCB. To achieve high hydrogen yield, the substrate used in the fermentation process must contain low HCB because they will end up consuming all the produced hydrogen.

The pretreatment method for food waste and its optimum working conditions are still challenging because it depends on the substrate and anaerobic digestion conditions. Therefore, this study attempts to compare the effect of heat pretreatment and ultraviolet (UV) radiation pretreatment on food waste in terms of its potential in HCB reduction and the effect on available fermentable sugar.

\section{MATERIALS AND METHODS}

\section{Food Waste Sample Preparation}

Food wastes were collected from several cafeterias in Universiti Malaysia Pahang. After removing the bones and unnecessary solid components, the food wastes were ground using a blender (Panasonic, Malaysia) to a small particle size enough to pass through a $2 \mathrm{~mm}$ sieve. The ground wastes were then stored in a sealed bag and kept in the chiller at $4{ }^{\circ} \mathrm{C}$ and thawed prior to use.

\section{Characterization of Food Waste}

The characteristics of food waste such as total solids, volatile solids and moisture content were measured according to standard methods [11]. The food wastes were diluted with distilled water before measuring $\mathrm{pH}$ at triplicates using a $\mathrm{pH}$ meter (Mettler Toledo, Switzerland).

\section{Carbohydrate Determination}

Iodine test was performed by adding 2 to 3 drops of Iodine reagent into $1 \mathrm{~mL}$ of sample in a clean test tube. The colour change of the solution was observed. For the dinitrosalicyclic acid (DNS) test, many known concentrations of glucose solutions were used to construct a standard curve for glucose analysis. The sample $(1 \mathrm{~g})$ was diluted with $9 \mathrm{~mL}$ of distilled water, and the mixture was shaken vigorously. About $1 \mathrm{~mL}$ of DNS reagent was added to $1 \mathrm{~mL}$ of the sample solution, and the test tube was covered with aluminium foil. The mixture was vortexed for 10 seconds and then boiled for 10 minutes to develop red-brown colour. The mixture was cooled under running tap water, and $10 \mathrm{~mL}$ of distilled water was added to stabilize the colour. The absorbance was read at $540 \mathrm{~nm}[12]$.

\section{Sample Pretreatment}

The heat pretreatment was conducted by placing each sample in the water bath at $70{ }^{\circ} \mathrm{C}, 80{ }^{\circ} \mathrm{C}$ and $90{ }^{\circ} \mathrm{C}$ for 15 minutes and 30 minutes [10]. The UV pretreatment was conducted by exposing the samples to UV radiation for 10,15 and 30 minutes [10]. After the pretreatment, the bottle was cooled to room temperature (if necessary) and stored at $4{ }^{\circ} \mathrm{C}$ until use.

\section{Screening of Microorganism}

About $1 \mathrm{~g}$ of sample was transferred to a $9 \mathrm{~mL}$ distilled water to make a $10^{-1}$ dilution and was shaken vigorously. The dilution step was repeated in order to get the appropriate colonies number on the plate. A $0.1 \mathrm{~mL}$ of bacterial dilution was aseptically transferred to the agar plates, and the mixture was spread with an L-shaped glass rod that has been sterilized. The plates were incubated at an inverted position for 24 hours at $37^{\circ} \mathrm{C}$. The colonies which appeared on the plate were subjected to morphological characterization and catalase test to identify the colonies.

\section{Characterization of Microorganism}

A Gram stain procedure was conducted on the bacterial colonies to determine their morphological characteristics. A smear of the bacterial was prepared. A small number of bacteria was aseptically transferred to the centre of a clean glass slide using an inoculation loop and mixed with a drop of water. The slide was passed through a Bunsen burner flame to heat fix and kill the bacteria. The smear was flooded with crystal violet for 30 seconds and rinsed with water. Then, the smear was covered with Gram's iodine mordant for 1 minute and rinsed with water. Next, acetone was used to decolourize for 30 - 60 seconds, and the slide was rinsed with water. The slide was counterstain with safranin for 1 minute and rinsed again with water. The slide was dried gently before observed under a microscope with immersion oil [13].

A catalase test was conducted by transferring $3 \%$ hydrogen peroxide to the clean glass slide. A small amount of bacterial colony was added to the glass slide using an inoculation loop and mixed. The appearance of gas bubbles shows a positive result, whereas the absence of gas bubbles represents a negative result [14].

\section{RESULTS AND DISCUSSION Characterization of Food Waste}

The characteristics of food waste samples are summarized in Table 1. Food waste A, B, C, and D were rice waste, vegetable and tempe waste, vegetable and French fries waste, and meat and vegetable waste, respectively. Total solids and volatile solids (VS) for all the samples were in the range of $16.64-25.08 \%$ and $90.55-96.00 \%$, respectively. All 
samples were acidic and contained about $74 \%$ to $83 \%$ moisture. It can be assumed that acidogenic bacteria or lactic acid bacteria were present in the samples since the $\mathrm{pH}$ is acidic. The high percentage of VS and moisture in food waste benefits microbial growth and becomes a potential substrate for hydrogen production [15].

Table 1. Characteristics of food waste samples

\begin{tabular}{lcccc}
\hline Parameters & Food waste A & Food waste B & Food waste C & Food waste D \\
\hline Total solids, \% & 25.08 & 21.85 & 20.31 & 16.64 \\
Volatile solids, \% & 96.00 & 94.18 & 92.29 & 90.55 \\
Moisture, \% & 74.92 & 78.15 & 79.69 & 83.36 \\
pH & 4.24 & 4.17 & 4.22 & 4.18 \\
\hline
\end{tabular}

\section{Carbohydrate Determination \\ lodine test}

Figure 1 illustrates the Iodine test results for Food waste A, B, C and D (from left to right). A positive result was observed for Food waste $\mathrm{A}$ and $\mathrm{C}$, where both formed dark blue colouration, indicating that both contain starch. A negative result was shown in Food waste B and D, indicating no starch present in both of these food wastes.

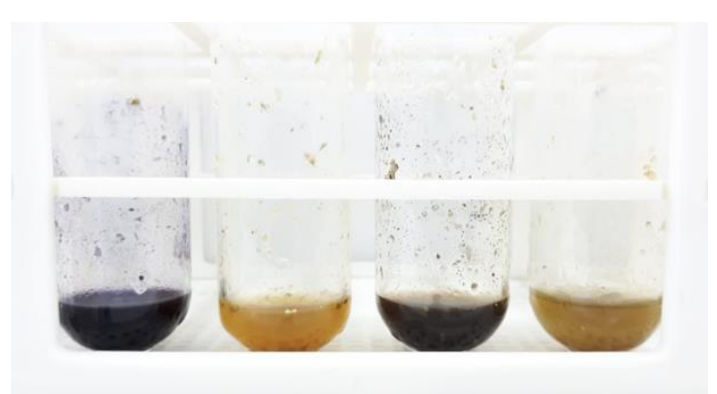

Figure 1. The Iodine test results for Food waste A, B, C and D (from left to right).

\section{Dinitrosalicylic Acid (DNS) Test}

Figure 2 illustrates the reducing sugar concentration in food waste samples before and after pretreatment at $70{ }^{\circ} \mathrm{C}, 80$ ${ }^{\circ} \mathrm{C}$ and $90{ }^{\circ} \mathrm{C}$ for 15 minutes. The initial concentration of reducing sugar in Food waste A, B, C and D were 2.2127 $\mathrm{mg} / \mathrm{mL}, 0.6555 \mathrm{mg} / \mathrm{mL}, 1.9193 \mathrm{mg} / \mathrm{mL}$ and $0.9143 \mathrm{mg} / \mathrm{mL}$ respectively. The concentration of reducing sugar in Food waste A was the highest, followed by Food waste C, Food waste D and Food waste B. There was a fluctuation in the reducing sugar concentration when the food waste samples pretreated at $70{ }^{\circ} \mathrm{C}, 80{ }^{\circ} \mathrm{C}$ and $90{ }^{\circ} \mathrm{C}$ for 15 minutes. Reducing sugar concentration in Food waste A increased from $2.2127 \mathrm{mg} / \mathrm{mL}$ to $3.087 \mathrm{mg} / \mathrm{mL}$ at $70{ }^{\circ} \mathrm{C}$, then decreased to 2.139 $\mathrm{mg} / \mathrm{mL}$ at $80{ }^{\circ} \mathrm{C}$ and rose again $2.554 \mathrm{mg} / \mathrm{ml}$ at $90^{\circ} \mathrm{C}$. The same patterns were observed on Food waste $\mathrm{C}$ and $\mathrm{D}$, in which heat pretreatment at $80^{\circ} \mathrm{C}$ recorded the lowest concentration of reducing sugar. Food waste B showed the lowest reducing sugar concentration at $90{ }^{\circ} \mathrm{C}$ pretreatment temperature.

Figure 3 represents the concentration of reducing sugar in food waste samples before and after pretreatment at $70{ }^{\circ} \mathrm{C}$, $80{ }^{\circ} \mathrm{C}$ and $90{ }^{\circ} \mathrm{C}$ for 30 minutes. There is a fluctuation in the reducing sugar concentration recorded. Overall, reducing sugar concentration in treated food waste was greater than those untreated except Food waste B. At 30 minutes pretreatment, most of the food waste recorded the highest reducing sugar concentration at $70{ }^{\circ} \mathrm{C}$ pretreatment temperature, which is similar when the pretreatment was conducted at 15 minutes.

The decomposition rates of glucose or oligomers are greater than the cellulose hydrolysis rate at higher temperatures [16]. This may be one of the reasons for not obtaining a high concentration of reducing sugars. As the temperature increases, the degree of polymerization of the soluble oligosaccharides decreases. This may be because the water ionization constant $\left(K_{\mathrm{w}}\right)$ increase with temperature $[17,18]$. The increase in ions concentration helps to degrade the glycosidic bonds in the starch and provides a very limited time for the oligosaccharides to be converted to monomers [19]. Moreover, glucose can also be isomerized to fructose or degraded to 5-hydroxymethylfurfural (5-HMF) and other products [20]. 


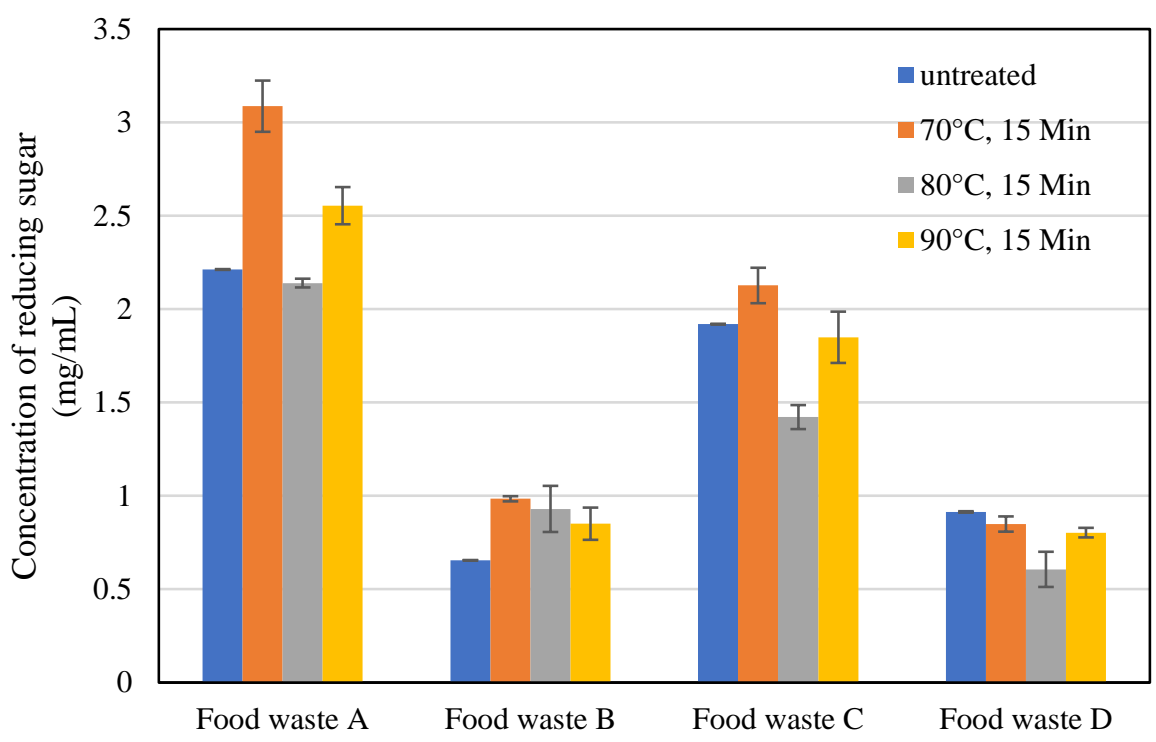

Figure 2. The concentration of reducing sugar in food waste samples before and after pretreatment at $70{ }^{\circ} \mathrm{C}, 80^{\circ} \mathrm{C}$ and $90{ }^{\circ} \mathrm{C}$ for 15 minutes. The error bars are \pm standard deviation.

In addition, increasing the pretreatment duration from 15 minutes to 30 minutes reduces the concentration of reducing sugar. From the obtained results, it can be seen that the reducing sugar concentration for Food waste A, B, C and D at 70 ${ }^{\circ} \mathrm{C}, 80{ }^{\circ} \mathrm{C}$ and $90{ }^{\circ} \mathrm{C}$ for $15 \mathrm{~min}$ were decreased when the pretreatment duration was extended to 30 minutes (Figure 2 and Figure 3). This may be due to further decomposition of reducing sugars to other degraded products such as 5-HMF, furfural, and glycol [21, 22].

The heat pretreatment at $70{ }^{\circ} \mathrm{C}$ for 15 and 30 minutes could be considered the best pretreatment compared to others since it recorded the highest reducing sugar concentration. This might indicate that heat pretreatment at this temperature can degrade starch into a smaller size of sugar fragment [23]. The reduction of reducing sugars at $80{ }^{\circ} \mathrm{C}$ and $90{ }^{\circ} \mathrm{C}$ may be due to the further degradation of sugar molecule due to longer exposure to heat [24].

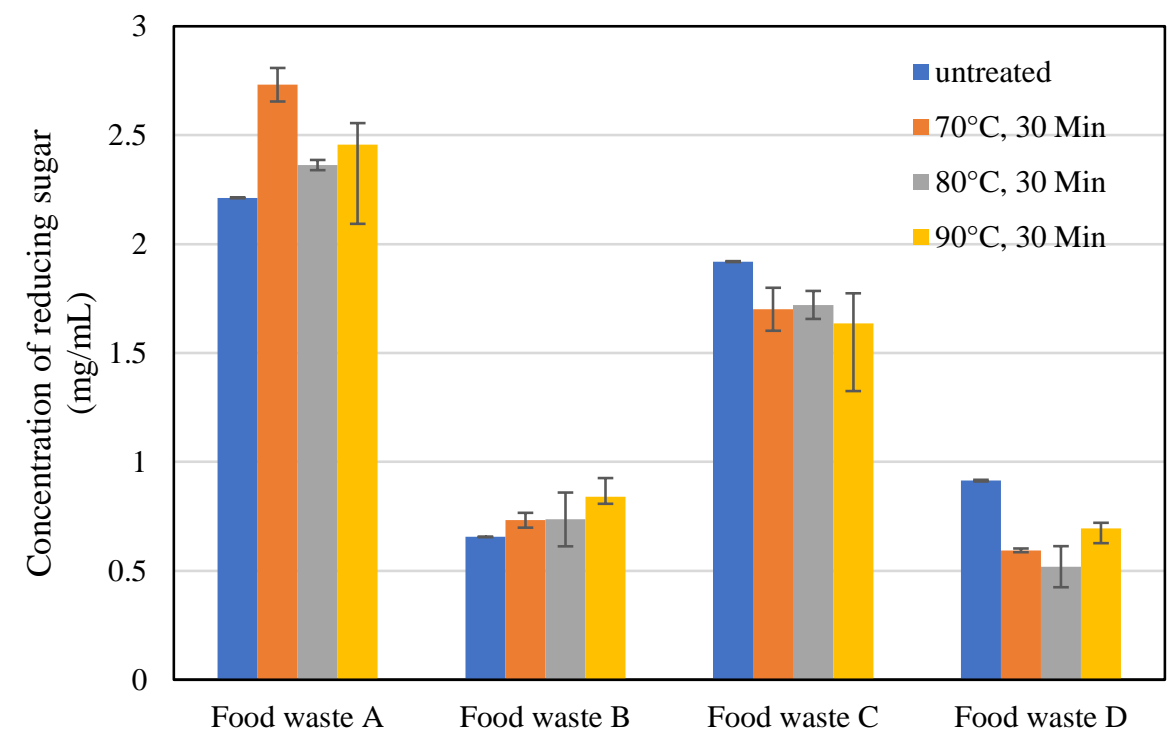

Figure 3. The concentration of reducing sugar in food waste samples before and after pretreatment at $70{ }^{\circ} \mathrm{C}, 80{ }^{\circ} \mathrm{C}$ and $90{ }^{\circ} \mathrm{C}$ for 30 minutes. The error bars are \pm standard deviation.

Figure 4 illustrates the concentration of reducing sugar in food waste samples before and after pretreatment under UV radiation for 10, 15 and 30 minutes. The concentration of reducing sugar in untreated Food waste A, B, C and D were $2.2127 \mathrm{mg} / \mathrm{mL}, 0.6555 \mathrm{mg} / \mathrm{mL}, 1.9193 \mathrm{mg} / \mathrm{mL}$ and $0.9143 \mathrm{mg} / \mathrm{mL}$ respectively. The concentration of reducing sugar in food waste samples after UV radiation pretreatment recorded a variation in trend. Food waste A recorded a considerable increase in reducing sugar concentration after 10 mins of UV radiation. However, it decreased as the UV radiation increased. Nevertheless, the reducing sugar concentration after 30 mins UV radiation was still higher than those of untreated. Food waste B, C, and D recorded decreasing or almost the same reducing sugar concentration after all UV radiation pretreatments than untreated. It is reported that $\mathrm{UV}$ radiation is a potential postharvest treatment for fruits in 
increasing the quality of fruits while ripening. This includes a significant increase in total soluble sugar, fructose, and glucose, which was achieved by the up-regulation expressions of specific genes [25]. This has justified the increase in reducing sugar concentration in Food waste A after UV radiation treatment. Additionally, HPB might be survived under UV radiation compared to methanogens and other HCB due to spore presence [26].

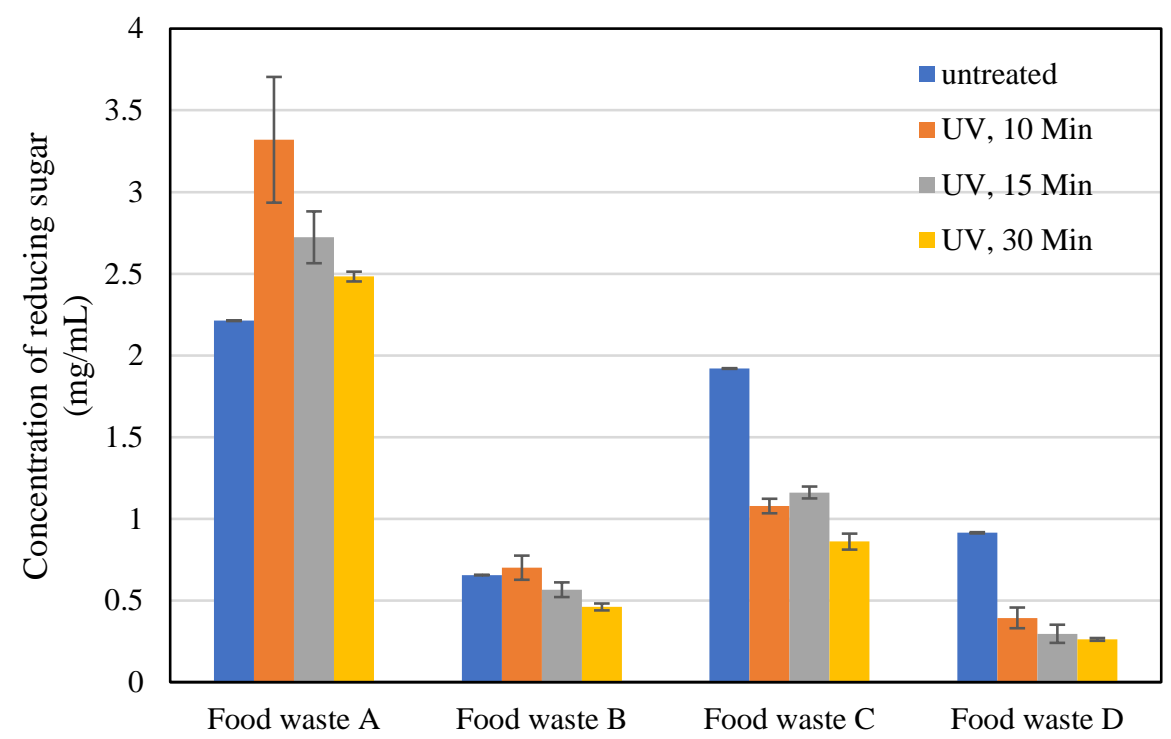

Figure 4. The concentration of reducing sugar in food waste samples before and after pretreatment at $70{ }^{\circ} \mathrm{C}, 80^{\circ} \mathrm{C}$ and $90{ }^{\circ} \mathrm{C}$ for 30 minutes. The error bars are \pm standard deviation.

\section{Bacterial colony characterization}

The number of bacterial colonies that grown on agar plates before and after pretreatment were similar. Nevertheless, bacterial colonies grown from treated samples were determined to grow slightly slower than those from treated samples (data not shown). Single colonies from the plates (of treated and untreated samples) were then sub-cultured on new agar plates to study the morphology of the bacterial colony. The characteristics of different colony patterns found on the agar plates are summarized in Table 2. Any morphologically similar colonies found from more than one plate was excluded in the discussions since the aim was to determine the potential variation of bacterial species in the samples.

Table 2. The characteristics of bacterial colonies from food waste samples observed on agar plates.

\begin{tabular}{cccccccc}
\hline $\begin{array}{l}\text { Bacterial } \\
\text { colonies }\end{array}$ & Form & Elevation & Margin & $\begin{array}{c}\text { Optical } \\
\text { property }\end{array}$ & Appearance & Pigmentation & Texture \\
\hline 1 & Irregular & Flat & Undulate & Translucent & Dull & White & Smooth \\
2 & Punctiform & Flat & Entire & Translucent & Shiny & Cream & $\begin{array}{c}\text { Smooth } \\
3\end{array}$ \\
Circular & Flat & Entire & Opaque & Shiny & Cream & Smooth \\
4 & Irregular & Flat & Lobate & Opaque & Dull & White & Smooth \\
5 & Circular & Flat & Entire & Opaque & Shiny & Yellow & Smooth \\
6 & Circular & Convex & Entire & Opaque & Shiny & Cream & Smooth \\
7 & Circular & Flat & Entire & Translucent & Dull & White & Smooth \\
8 & Circular & Flat & Lobate & Translucent & Dull & White & Smooth \\
9 & Irregular & Flat & Lobate & Opaque & Shiny & Cream & Rough \\
10 & Circular & Flat & Entire & Opaque & Shiny & Cream & Smooth \\
11 & Circular & Flat & Entire & Opaque & Shiny & Orange & Smooth \\
\hline
\end{tabular}

\section{Bacterial colony characterization}

Out of 11 bacterial colonies, four bacterial colonies were observed gram-negative, and seven bacterial colonies were observed gram-positive. The results showed that Bacteria 1 was gram-negative coccobacilli, Bacteria 2, 3, 5, 7, 10 and 11 were gram-positive bacilli, Bacteria 4 was gram-negative bacilli, Bacteria 6 and 9 were gram-negative cocci, and Bacteria 8 was gram-positive coccobacilli. Table 3 summarize the gram stain results and morphology of each colony. Figure 5 and 6 show the observation of gram-positive and gram-negative colonies under the microscope (100x magnification). Based on morphological characteristics of bacterial colonies, bacteria 6 might be Pseudomonas sp. and the result was supported by the findings of Hamid et al. [27]. Bacteria 7 and 9 might be Bacillus sp. when compared to 
the findings from Hamid et al. [28]. It can be assumed that Bacteria 10 might be Staphylococci sp. or Micrococci sp. [29]. Pseudomonas sp. and Bacillus sp. are HPB. Both of them are capable of producing hydrogen in anaerobic condition may be due to facultative anaerobes. From the obtained results, it can be said that Food waste A, B and D pretreated at heat for $70{ }^{\circ} \mathrm{C}$ for 15 and $30 \mathrm{~min}$ and UV for $15 \mathrm{~min}$ had a high possibility to retain HPB while removing HCB.

Table 3. Gram stain and morphology of bacterial colonies from food waste samples before and after pretreatment.

\begin{tabular}{ccccc}
\hline $\begin{array}{c}\text { Bacterial } \\
\text { colonies }\end{array}$ & Pretreatment condition & Food waste & Gram stain & Morphology \\
\hline Bacteria 1 & Heat $\left(80^{\circ} \mathrm{C}\right), 30 \mathrm{~min}$ & $\mathrm{D}$ & Negative & Coccobacilli \\
Bacteria 2 & Heat $\left(70^{\circ} \mathrm{C}\right), 15 \mathrm{~min}$ & A & Positive & Cocci \\
Bacteria 3 & Heat $\left(90^{\circ} \mathrm{C}\right), 15 \mathrm{~min}$ & $\mathrm{C}$ & Positive & Cocci \\
Bacteria 4 & Heat $\left(80^{\circ} \mathrm{C}\right), 15 \mathrm{~min}$ & A & Negative & Bacilli \\
Bacteria 5 & Heat $\left(80^{\circ} \mathrm{C}\right), 15 \mathrm{~min}$ & $\mathrm{C}$ & Positive & Cocci \\
Bacteria 6 & Heat $\left(70^{\circ} \mathrm{C}\right), 15 \mathrm{~min}$ & $\mathrm{D}$ & Negative & Cocci \\
Bacteria 7 & $\mathrm{UV}, 15 \mathrm{~min}$ & A & Positive & Bacilli \\
Bacteria 8 & - & D & Positive & Coccobacilli \\
Bacteria 9 & Heat $\left(70^{\circ} \mathrm{C}\right), 30 \mathrm{~min}$ & B & Negative & Cocci \\
Bacteria 10 & Heat $\left(70^{\circ} \mathrm{C}\right), 30 \mathrm{~min}$ & A & Positive & Cocci \\
Bacteria 11 & Heat $\left(70^{\circ} \mathrm{C}\right), 15 \mathrm{~min}$ & $\mathrm{D}$ & Positive & Cocci
\end{tabular}
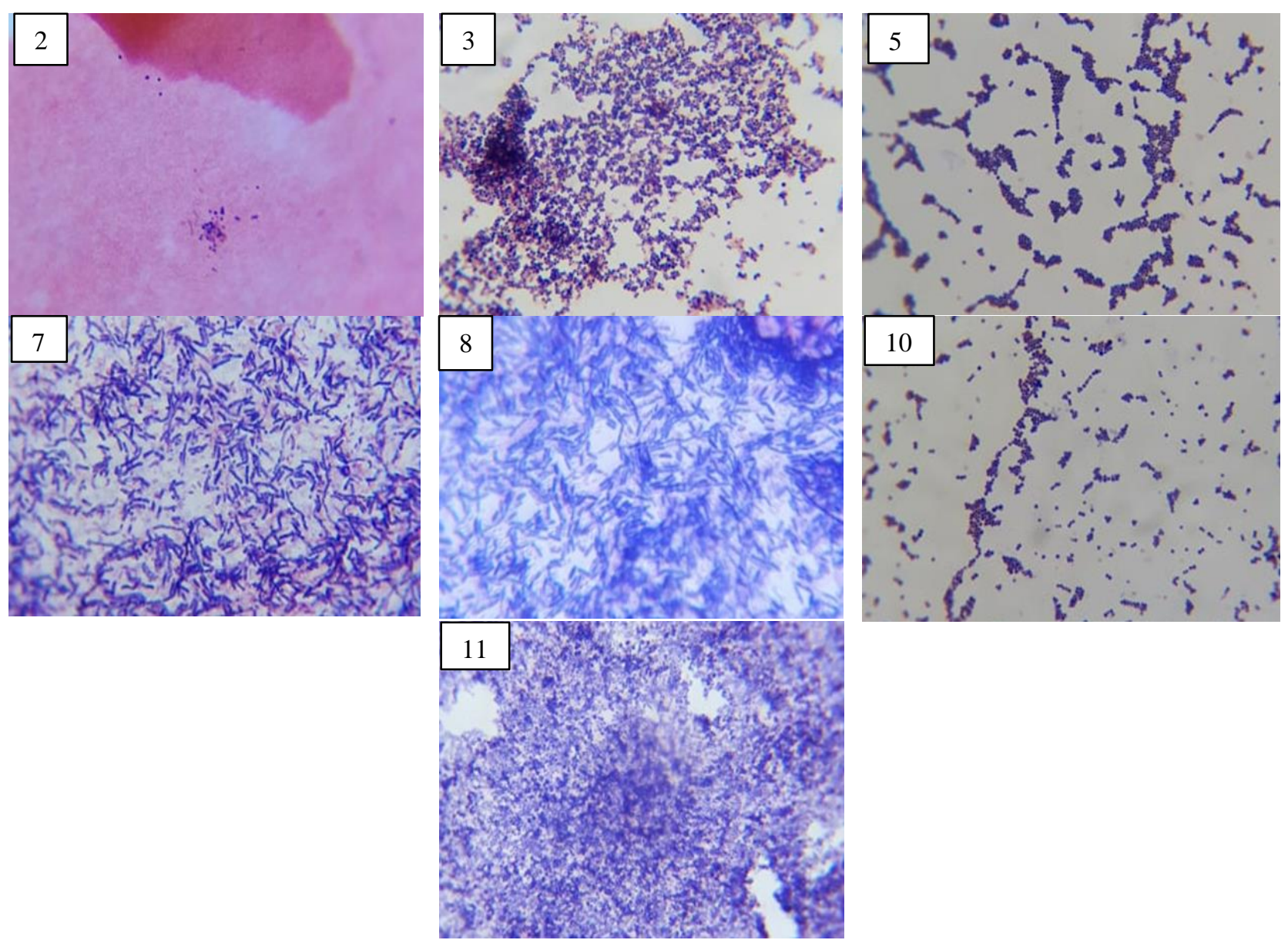

Figure 5. The morphology of Gram-positive bacteria when observed under microscope with 100× magnification.
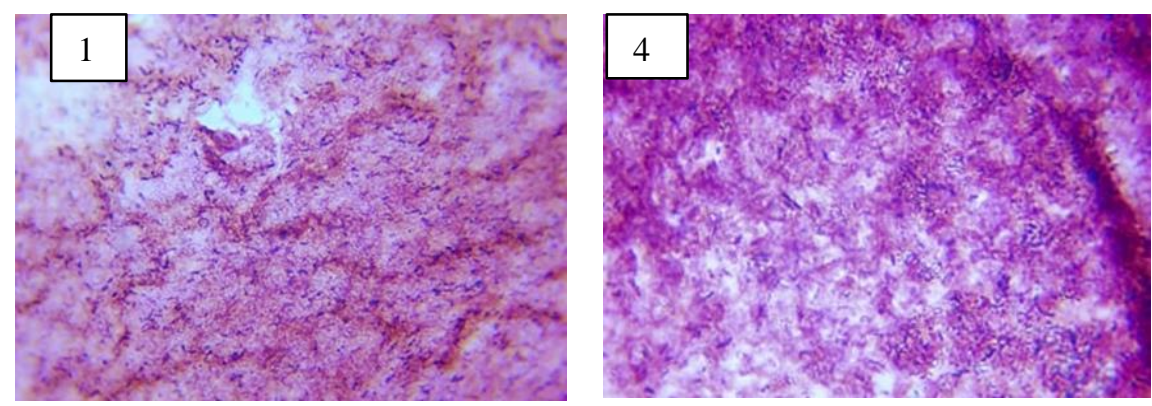

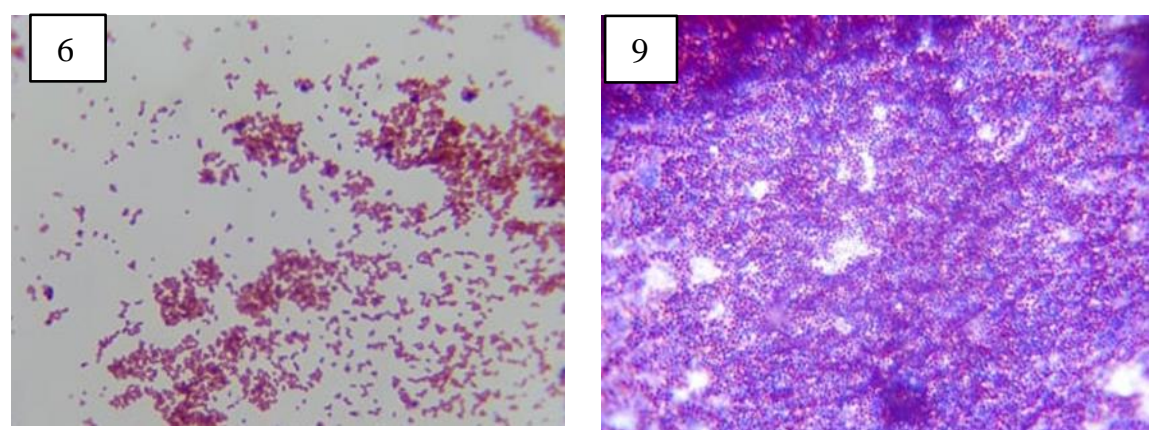

Figure 6. The morphology of Gram-negative bacteria when observed under microscope with 100x magnification.

\section{Catalase test}

Table 4 displays the catalase test results on bacterial colonies from food waste samples before and after pretreatment. In this study, only three bacteria were recorded as negative result: Bacteria 2, 7 and 8, while the other eight bacteria showed a positive result. From the results, it can be assumed that Bacteria 2, 7 and 8 were possibly HPB because most of the HPB are catalase-negative whereas bacteria 1,3, 4, 5, 6, 9, 10 and 11 were HCB because they gave a catalase-positive result. Besides, there was no reduction of catalase-positive after pretreatment because HPB might not grow since the bacteria were grown in aerobic condition.

Table 4. Gram stain and morphology of bacterial colonies from food waste samples before and after pretreatment.

\begin{tabular}{cccc}
\hline Bacterial colonies & Pretreatment condition & Food waste & Catalase \\
\hline Bacteria 1 & Heat $\left(80^{\circ} \mathrm{C}\right), 30 \mathrm{~min}$ & $\mathrm{D}$ & + \\
Bacteria 2 & Heat $\left(70^{\circ} \mathrm{C}\right), 15 \mathrm{~min}$ & $\mathrm{~A}$ & - \\
Bacteria 3 & Heat $\left(90^{\circ} \mathrm{C}\right), 15 \mathrm{~min}$ & $\mathrm{C}$ & + \\
Bacteria 4 & Heat $\left(80^{\circ} \mathrm{C}\right), 15 \mathrm{~min}$ & $\mathrm{~A}$ & + \\
Bacteria 5 & Heat $\left(80^{\circ} \mathrm{C}\right), 15 \mathrm{~min}$ & $\mathrm{C}$ & + \\
Bacteria 6 & Heat $\left(70^{\circ} \mathrm{C}\right), 15 \mathrm{~min}$ & $\mathrm{~A}$ & + \\
Bacteria 7 & $\mathrm{UV}, 15 \mathrm{~min}$ & $\mathrm{D}$ & - \\
Bacteria 8 & - & $\mathrm{B}$ & - \\
Bacteria 9 & Heat $\left(70^{\circ} \mathrm{C}\right), 30 \mathrm{~min}$ & $\mathrm{~A}$ & + \\
Bacteria 10 & Heat $\left(70^{\circ} \mathrm{C}\right), 30 \mathrm{~min}$ & $\mathrm{D}$ & + \\
Bacteria 11 & Heat $\left(70^{\circ} \mathrm{C}\right), 15 \mathrm{~min}$ & + \\
\hline
\end{tabular}

\section{CONCLUSION}

From this study, it can be concluded that heat pretreatment at $70{ }^{\circ} \mathrm{C}$ for 15 and 30 minutes can reduce the number of bacterial colonies. UV radiation pretreatment for 15 minutes to 30 minutes had a bactericidal effect since the growth of bacterial colonies decreased. It can be suggested that heat pretreatment at $70{ }^{\circ} \mathrm{C}$ for 15 and 30 minutes and $\mathrm{UV}$ radiation pretreatment for 15 minutes can retain HPB while removing HCB. There are high possibilities that Bacteria 2, 7 and 8 were HPB since they presented catalase-negative results. However, the bacteria cannot be identified using the current biochemical test applied. It is envisaged that physical pretreatment of food waste could be served as a substrate for fermentative hydrogen producing bacteria, hence future applications.

\section{ACKNOWLEDGEMENT}

The author would like to thank Universiti Malaysia Pahang for funding this work.

\section{REFERENCES}

[1] Energy Information Administration. (2010). International Energy Outlook 2010. Washington, DC: U.S. Department of Energy.

[2] Gopalakrishnan, B., Khanna, N., \& Das, D. (2019). Dark-Fermentative Biohydrogen Production. In A. Pandey, S. Mohan, J. Chang, P. Hallenbeck, \& C. Larroche (Eds.), Biomass, Biofuels, Biochemicals: Biohydrogen (2nd ed., pp. 79-122). Amsterdam, Amsterdam, Netherlands: Elsevier.

[3] Food and Agriculture Organization. (2011). Global food losses and food waste—Extent, causes and prevention. Rome, Italy: Food and Agriculture Organization.

[4] Environmental Protection Agency. (2016). EPA recognizes New England institutions for diverting food waste. Retrieved from https://archive.epa.gov/epa/newsreleases/epa-recognizes-new-england-institutions-diverting-food-waste.html 
The Star. (2016). Malaysians waste 15,000 tonnes of food daily. Retrieved from https://www.thestar.com.my/news/nation/2016/05/24/malaysians-waste-15000-tonnes-of-food-daily/

[6] Kapdan, I. K., \& Kargi, F. (2006). Bio-hydrogen production from waste materials. Enzyme and Microbial Technology, 38(5), 569-582.

[7] Parihar, R. K., \& Upadhyay, K. (2015). Production of Bio-Hydrogen Gas from Wastewater by Anaerobic Fermentation Process: A Review. International Journal of Chemical Studies, 3(3), 7-14.

[8] Preethi, Mohamed Usman, T.M., Banu, J.R., Gunasekaran, M., \& Kumar, G. (2019). Biohydrogen production from industrial waste water: An overview. Bioresource Technology Reports 7, 100287.

[9] Karlsson, A., Truong, X. B., Gustavsson, J., Svensson, B. H., Nilsson, F., \& Ejlertsson, J. (2011). Anaerobic treatment of activated sludge from Swedish pulp and paper mills - biogas production potential and limitations. Environmental Technology, 32(14), 1559-1571.

[10] Wong, Y.M., Wu, T.Y., \& Juan J.C. (2014). A review of sustainable hydrogen production using seed sludge via dark fermentation. Renewable and Sustainable Energy Reviews, 34, 471-482.

[11] American Public Health Association (APHA). (2005). Standard Methods for the Examination of Water and Wastewater, 21st ed. Washington, D. C.: American Public Health Association.

[12] Miller, G.L. (1959). Use of dinitrosalicylic acid reagent for determination of reducing sugar. Anal. Chem., 31, 426-428.

[13] Shuler, M., \& Kargi, F. (2002). Bioprocess engineering: Basic concepts, $2^{\text {nd }}$ ed. Upper Saddle River, N.J.: Prentice-Hall Inc.

[14] Reiner, K. (2016). Catalase test protocol. American Society for Microbiology.

[15] Li, M., Zhao, Y., Guo, Q., Qian, X., \& Niu, D. (2008a). Bio-hydrogen production from food waste and sewage sludge in the presence of aged refuse excavated from refuse landfill. Renewable Energy, 33(12), 2573-2579.

[16] Zhao, Y., Wang, H. T., Lu, W. J., \& Wang, H. (2011). Combined supercritical and subcritical conversion of cellulose for fermentable hexose production in a flow reaction system. Chemical Engineering Journal, 166(3), 868-872.

[17] Mochidzuki, K., Sakoda, A., \& Suzuki, M. (2003). Liquid-phase thermogravimetric measurement of reaction kinetics of the conversion of biomass wastes in pressurized hot water: A kinetic study. Advances in Environmental Research, 7(2), 421-428.

[18] Tanaka, M., Takamizu, A., Hoshino, M., Sasaki, M., \& Goto, M. (2012). Extraction of dietary fiber from Citrus junos peel with subcritical water. Food and Bioproducts Processing, 90(2), 180-186.

[19] Rubio, M., Tortosa, J. F., Quesada, J., \& Gómez, D. (1998). Fractionation of lignocellulosics. Solubilization of corn stalk hemicelluloses by autohydrolysis in aqueous medium. Biomass and Bioenergy, 15(6), 483-491.

[20] Kabyemela, B. M., Takigawa, M., Adschiri, T., Malaluan, R. M., \& Arai, K. (1998). Mechanism and Kinetics of Cellobiose Decomposition in Sub- and Supercritical Water. Industrial \& Engineering Chemistry Research, 37(2), 357-361.

[21] Aida, T. M., Shiraishi, N., Kubo, M., Watanabe, M., \& Smith, R. L. (2010). Reaction kinetics of d-xylose in sub- and supercritical water. The Journal of Supercritical Fluids, 55(1), 208-216.

[22] Prado, J. M., Follegatti-Romero, L. A., Forster-Carneiro, T., Rostagno, M. A., Filho, F. M., \& Meireles, M. A. (2014). Hydrolysis of sugarcane bagasse in subcritical water. The Journal of Supercritical Fluids, 86, 15-22.

[23] Barua, V. B., \& Kalamdhad, A. S. (2017). Effect of various types of thermal pretreatment techniques on the hydrolysis, compositional analysis and characterization of water hyacinth. Bioresource Technology, 227, 147-154.

[24] Zou, X., Zhu, C., Wang, Q., \& Yang, G. (2019). Catalytic dehydration of hexose sugars to 5-hydroxymethylfural. Biofuels, Bioproducts and Biorefining, 13(1), 153-173.

[25] Hu, L., Yang, C., Zhang, L., Feng, J., \& Xi, W. (2019). Effect of Light-Emitting Diodes and Ultraviolet Irradiation on the Soluble Sugar, Organic Acid, and Carotenoid Content of Postharvest Sweet Oranges (Citrus sinensis (L.) Osbeck). Molecules, 24(19): 3440.

[26] Wang, H., Fang, M., Fang, Z., \& Bu, H. (2010). Effects of sludge pretreatments and organic acids on hydrogen production by anaerobic fermentation. Bioresource Technology, 101(22), 8731-8735.

[27] Hamid, B., Jehangir, A., Baba, Z. A., Wani, M. A., \& Khan, I. (2019a). Isolation and characterization of psychrotrophic proteolytic bacteria from landfill site under temperate climatic conditions of Kashmir Himalaya. PeerJ Preprints.

[28] Hamid, B., Jehangir, A., Baba, Z. A., \& Fatima, S. (2019b). Isolation and Characterization of Cold Active Bacterial Species from Municipal Solid Waste Landfill Site. Research Journal of Environmental Sciences, 13(1), 1-9.

[29] Saha, A., \& Santra, S. C. (2014). Isolation and Characterization of Bacteria Isolated from Municipal Solid Waste for Production of Industrial Enzymes and Waste Degradation. Journal of Microbiology \& Experimentation, 1(1), 12-19. 